\title{
HIDDEN PATTERNS OF SELL FOR FRESH AGRICULTURE PRODUCE BY FARMERS NEAR TO APMC AHMEDABAD.
}

\section{PATRONES OCULTOS DE VENTA PARA PRODUCTOS DE AGRICULTURA FRESCA POR AGRICULTORES CERCA DE APMC AHMEDABAD.}

Neepa Shah

Department of Computer Science, Gujarat Vidyapith, India, email: neepa@gujaratvidyapith.org

\begin{abstract}
After delisting of fresh agriculture produce at APMC Ahmedabad, there is no change in farmers' behavior to sell their produce. They still prefer to sell produce through traders and brokers in regulatory body such as APMC. This paper is about the behavior of farmers to sell produce. This study derives some hidden patterns which are previously unknown. The pattern shows that to whom farmers want to sell produce; when they get success or failure to get market for the produce. It also shows behavioral pattern of farmers for different income groups. A pattern of auction in APMC market and how many farmers are agree with the auction and its beneficence. One of the most important parameter for the fresh agriculture produce is the timeframe within that produce get sold. This paper shows the pattern of who is able to sell produce in required timeframe. At last a study of those farmers who were failed to sell produce within required timeframe and what they do with that unsold produce and alternatives available to them.

Keywords: Delisting of fresh Agriculture produce, APMC, Demand and Supply of produce, Auction in APMC, Timeframe of sell of produce, Unsold produce.
\end{abstract}


Sustainability, Agri, Food and Environmental Research, (ISSN: 0719-3726), 8(X), 2020 http://dx.doi.org/10.7770/safer-VONO-art1995

Después de la exclusión de los productos agrícolas frescos en APMC Ahmedabad, no hay cambios en el comportamiento de los agricultores para vender sus productos. Todavía prefieren vender productos a través de comerciantes y corredores en organismos reguladores como APMC. Este documento trata sobre el comportamiento de los agricultores para vender productos. Este estudio deriva algunos patrones ocultos que anteriormente se desconocían. El patrón muestra que a quién los agricultores quieren vender productos; cuando tienen éxito o no consiguen comercializar el producto. También muestra el patrón de comportamiento de los agricultores para diferentes grupos de ingresos. Un patrón de subasta en el mercado APMC y cuántos agricultores están de acuerdo con la subasta y su beneficencia. Uno de los parámetros más importantes para los productos agrícolas frescos es el plazo dentro del cual se venden los productos. Este documento muestra el patrón de quién puede vender productos en el plazo requerido. Finalmente, un estudio de aquellos agricultores que no pudieron vender productos dentro del plazo requerido y lo que hacen con ese producto no vendido y las alternativas disponibles para ellos.

Palabras clave: exclusión de productos agrícolas frescos, APMC, demanda y oferta de productos, subasta en APMC, calendario de venta de productos, productos no vendidos.

\section{Introduction}

Delisting of fresh agriculture produce is announced by government of India, in the beginning of year 2015. Still many states has not delisted fresh produce. Government of Gujarat has taken the decision about delisting of fresh agriculture produce in May 2015. Currently many farmers are unknown about this decision, in fact this decision is very important for farmer community and definitely going to effects them in near future. Many farmers are unknown about the fact that there is vast difference between rate of sell of produce at APMC and retail market Neepa Shah (2017), Horticultural Statistics at a Glance (2015).

There are many reasons for farmers who still choose APMC to sell their vegetables and fruits produce. This paper is a study of such farmers and current market situation for the farmers. If government want to remove middleman and let farmer and end-customer directly meet in the market than what are the alternatives available in current era. Standardization of rate of produce for farmers is also 
necessary to remove redundancy of rate at various places. Simultaneously there should be a powerful supply chain management for all perishable produce.

Let us first study about some details on existing supply chain management. This study will help us to find entities that play a major role to enforce selling activities and also benefited for farmers. Study of supply chain management affected by many parameters and few are given below:

- Well planned cold Storage and other storage

- Marketing of Agriculture Produce in the country and foreign country

- Transportation infrastructure

- Credit facilities for farmers

Storage: Three tire storage system is currently exist in the country. National/State level, District level and village level. In villages, storage options are exist but there is no facilities for fresh agriculture produce which is perishable items. Even at state level and central level, management of perishable cargo is very poor and inefficient so there is lots of trouble to sell perishable produce in international markets Gaurav Bissa, Vijay Vyas (2014). There are only six centers for perishable cargo (CPC) in the country and capacity per annum is less. Price rate for this cargo vary at different centers with large margin.

Market: Market of the perishable agriculture produce takes very important role in context of farmer's behavior after delisting the produce. Multiple channel of distribution eat pocket from farmers and end customers. On the other hand there are lots of opportunities lies for our produce at outside local world. Farmers who produce different vegetables and fruits are unaware about global demand. They even don't know the quality of their produce with respect to global market and this is the main reason that middlemen take fruits of their hard work. Now farmers must know about globalization and how this globalization had made deep impact on farmers and agriculture marketing A.Vadivelu and B.R. Kiran (2013) Negi, Saurav and Anand, Neeraj. (2015). We need to provide good information system that works with the details of agriculture market and demand of produce. Farmers in the villages are having poor information. An agriculture information system with real time data can help farmers and agriculture marketing. So development in this direction is demand of better market and advisory system for farmers. This advisory system should not 
affected by black market and should not be a footstep for creating an artificial demand for agriculture produce.

Some agriculture information systems have been already in the market. "Bhav Puchhiye" is one of the good application developed by Media lab-IITM, but people do not show much interest for latest rate of agriculture produce. Many other system are also failed due to one or other reasons. Awareness about technology and usage in their current era is very important to understand for farming community. Literacy about technology and usefulness of the data in real life is required to understand by farmers and end customers too.

Commission rate is not going to reduce despite of good infrastructure has taken place. Licensing of commission agents/ traders in the regulatory body creates monopoly situation in many states. This act as a major barrier for novel concepts, new entrepreneur, and new technology without any competition Singh, Sukhpal and Singla, Naresh (2010). Foreign Direct Investment also plays major role after restriction were lifted up in 2006. Many multinational companies are ready to enter in our market. Still there are no concrete steps taken by government for benefits of farmers Angad Singh Maravi, (2015) K.V. Praveen and A. Suresh (2015).

Credits: Farmers are facing financial problems due to uncertainty of weather, market and environment effects. Agriculture credit is distributed by commercial banks, rural banks and cooperative banks for the help of farmers Gaurav Bissa, Vijay Vyas (2014).

Transportation: In our country most of the states are well connected and even within states transportation is available for town and villages. Gujarat, Karnataka, Maharashtra, Kerala are well connected to villages but in some states this infrastructure is rarely available. This makes adverse effect to remotely located farmers.

After looking at the current scenario of national and international market of the agriculture produce. It seems that it is their innocence (ignorance) about knowledge of market. One must aware them by providing them required information. This paper shows some patterns of sell and provide alternatives to make maximum benefits. Coming sections are about different patterns of sell and purchase in APMC 
Ahmedabad and nearby villages' farmers. This pattern will help them to understand current trends and lead them to their need.

Given are objectives of the study for farmer community.

1) Study of current trend of farmers where they prefer to sell produce.

2) If conventional process at regulatory body is changed then what is the view of farmers about direct selling. (Possible solution of the problem).

3) Find out the alternatives for farmers apart from local regulatory body.

\section{MATERIAL AND METHODS}

Study site: Gujarat State government and central government both have to take decision to improve primitive facilities to farmers. Apart from primitive facilities at APMC, other basic things also affect the farmer and draw them to take certain decisions. One of the important parameter is literacy. This rate increase the ability to cop up with new technology and mainly they will come to know about the global scenario of the produce. Once they know the benefits by accessing this information they will become demanding for their produce, thus literacy is very important. In Gujarat state, rate of literacy is comparatively good and majority of farmers' community is connected to APMC of state or district for their required data and other information. Another parameters is transportation. Produce must reach to the market within required timeframe to get good revenue. In Gujarat, most of the towns are connected through road and approachable to the villages. Here are some details about Gujarat state:

Literacy rate: $70 \%$

Primary APMC: 166

Secondary APMC: 232.

Data of table (1) shows that good infrastructure at ground level is available for farmers in Gujarat state. Most of the district of Gujarat state are having satisfactory number of primary and secondary APMC. Using technology, such infrastructure can be well equipped and it will be best for serving agencies of farmers and end customers too. There are many scope of development for the farmer community and narrow down the gap between farmers and end customers by providing best communication alternatives in the society. 
Sustainability, Agri, Food and Environmental Research, (ISSN: 0719-3726), 8(X), 2020 http://dx.doi.org/10.7770/safer-VONO-art1995

Table 1: Data about number of APMC in different district of Gujarat

\begin{tabular}{llllll}
\hline City/Town & $\begin{array}{l}\text { APMC/Wholesale } \\
\text { market }\end{array}$ & City/Town & $\begin{array}{l}\text { APMC/Wholesale } \\
\text { market }\end{array}$ & City/Town & $\begin{array}{l}\text { APMC/Wholesale } \\
\text { market }\end{array}$ \\
\hline Ahmedabad & 19 & Gandhinagar & 11 & Patan & 13 \\
Amreli & 11 & Jamnagar & 7 & Panchmahal & 24 \\
Anand & 15 & Junagadh & 15 & Porbandar & 2 \\
Banaskatha & 23 & Kheda & 21 & Rajkot & 17 \\
Bharuch & 21 & Kutchh & 8 & Sabarkatha & 29 \\
Bhavnagar & 11 & Mahesana & 18 & Surat & 37 \\
Dang & 1 & Narmada & 7 & Surendranagar & 11 \\
Dahod & 17 & Navsari & 12 & Vadodara & 32 \\
\hline
\end{tabular}

In coming section, we are going to discuss data about Ahmedabad APMC market for perishable produce and connected network. This can give us a blue print of relationship of farmers with regulatory body and lead us to the root of the problem.

Primary data collection: Primary data is collected by an interview with secretory of APMC, Ahmedabad, farmers of villages near Ahmedabad city and websites maintained by APMC, Agricultural \& Processed Food Products Export Development Authority(APEDA), National horticulture board (NHB). These sites provide information about the structure of market along with current rate of fruits and vegetables in the market. These rates are available in two categories - wholesale and retail. During the visit of the villages, approximately 50 to 55 villages had been visited with predefined questionnaires to the farmers and 517 farmers has been interviewed on random basis Neepa Shah (2017). This questionaries' includes questions in three different categories. First category is about general data of farmers with six different questions. Second category is about information of market, this questions were to know about farmer's knowledge about market that includes fifteen different questions. All questions in this category are multiple choice questions. Last category is to know farmers understanding about market and government policies.

Ahmedabad APMC is the biggest market for vegetable produce in the state. Daily income of the vegetables is 25000 to 27000 quintals (qt). It is a terminal 
market where traders and brokers (commission agent) work together for the farmers. According to APMC data only 9000 to 10000 qt. is daily consumption of vegetables in Ahmedabad city while remaining vegetables are sent to other APMC of the state and outside the state. Some vegetables are also sell to our neighbor countries and foreign countries too.

\section{RESULTS AND DISCUSSION}

Classification of Data: While working with the data collected from the different villages near Ahmedabad city, we have classify the data according to farmers choice to whom he/she likes to sell produce. There are mainly four categories for them to sell produce as stated below:

- Broker: In APMC, a middleman who works between farmers and traders. APMC has defined a list of authorized broker for vegetable market, only those can make a deed in the market.

- Trader: The person who purchase farmer's agriculture produce in the market are trader. Some transactions are direct transaction where only farmer and trader make a deed in the market. APMC has also declared a list of authorized traders of market.

- Shopkeeper: Shopkeeper are persons who sell fruit and vegetables to the end customers. It includes malls, special vegetables and fruit shops, fruits and vegetables service provider through the Internet or mobile services.

- Customer: The person who purchase these produce for their daily usage called customer or end customer.

To study about different pattern of sell in the market, given table (2) shows preliminary details from the survey and its results ratio with comparative analysis.

In the villages near to Ahmedabad city, most of the farmers prefer to sell their agriculture produce to brokers/traders. Very few farmers are interested to sell fruits and vegetables directly to end customers. These farmers are belonged to low income group. They have small amount of produce, so they can manage to sell directly to the end-customer in the market.

Now a days, on-line market and mall market are very popular, in this scenario, people purchase fruits and vegetables from such shops. This shopkeeper also wants to buy good produce with handsome rate so they purchase from the farmers for their shops or mall. These shopkeepers maintain a group of farmers for their required produce. Remaining farmers opt to work with brokers and traders in APMC because 
Sustainability, Agri, Food and Environmental Research, (ISSN: 0719-3726), 8(X), 2020 http://dx.doi.org/10.7770/safer-VONO-art1995

the city is well connected by road to surrounding villages, so farmers can easily reach to the market.

Table 2: Summary of response given by farmers who live nearby villages of Ahmedabad city

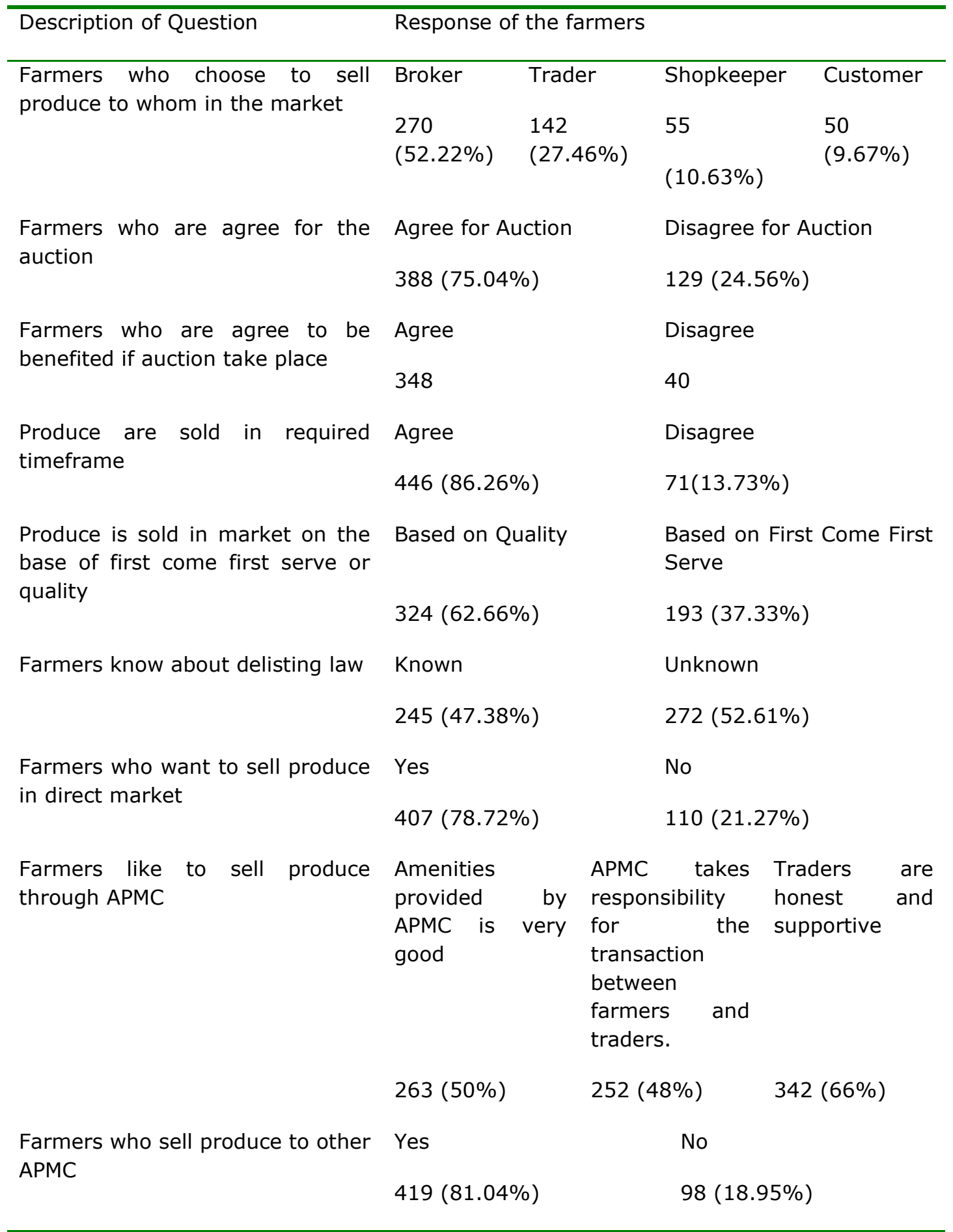


Sustainability, Agri, Food and Environmental Research, (ISSN: 0719-3726), 8(X), 2020 http://dx.doi.org/10.7770/safer-VONO-art1995

Classification of the data according to their income of farming is shown here. We have classified these data into four groups. First group is low range group where income is less than or equal to 50000 . Second group is medium range group where income is more than 50000 and less than 500000. Third group is upper medium group where income is more than 500000 and less than 1500000. Last group is upper group where income is more than 1500000. Given table is about different income group of farmers and their behavior pattern to sell agriculture produce in market.

Table 3: Statistics of farmers to whom they sell agriculture produce with different income range

\begin{tabular}{lllll}
\hline Income group \Types & Broker & Customer & Shopkeeper & Trader \\
\hline Low range & $141(53.00 \%)$ & $37(13.9 \%)$ & $23(8.64 \%)$ & 65 \\
& & & $(24.43 \%)$ \\
Medium range & 120 & $12(5.21 \%)$ & $32(13.91 \%)$ & 66 \\
& $(52.17 \%)$ & & $(28.69 \%)$ \\
Upper medium range & $5(35.71 \%)$ & $1(7 \%)$ & $0(0 \%)$ & $8(57 \%)$ \\
Upper range & $4(57.14 \%)$ & $0(0 \%)$ & $0(0 \%)$ & $3(42.85 \%)$ \\
\hline
\end{tabular}

Table 3 has been drawn using all data collected from the survey. Mainly data fall into first two ranges and last two ranges contains only 21 instances of farmer's data. In this data the upper medium range shows one instance of farmer who use to sell agriculture produce to customer. We might consider this data as an error because if a farmer's income is more than 500000 then amount of produce is also large. If a farmer opt to sell produce directly in the market to the customer than he/she need ample amount of time and manpower. This will definitely effect their other farming work. So we might consider this data as a typographical error or a reading error; otherwise it is possible that large family has divided the work in such a way so few family members can directly sell produce to customers. Given box plot graph in figure 1 shows data of all 517 instances of farmer's survey and top dot in the customer column is outlier for the data. 


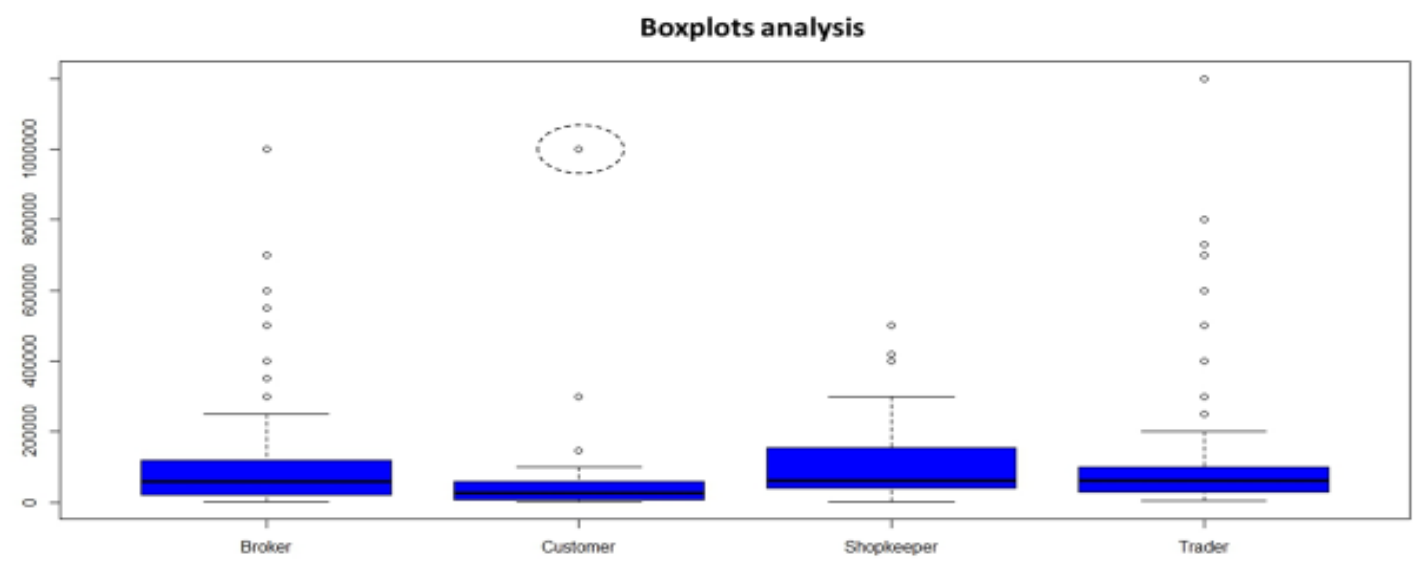

Figure 1: A Box-plot diagram of farmers who sell agriculture produce to different entities at APMC. Here X-ax shows different entities and $Y$-ax shows income of the farmers

In table 3, first two ranges of data are made by 496 instances of farmers. Mining these data will give more hidden pattern about farmer's behavior. So to achieve higher level of granularity we have applied more process to generate graph of figure (2) of income wise number of farmer using broker, trader, shopkeeper and customer classification. This is three dimensional data. Each bar contains information about total number of farmers and number of farmers in each category. In the graph, each bar represent range of Rs. 25000 but some income ranges doesn't have any instance of farmers so those income ranges are not appeared in the graph.

This graph is a representation of number of farmers in different income group and to whom they sell their agriculture produce. We can see red part of broker in the entire graph with a large area in almost all income groups. Green color in the bar for customer presents in first four bars, after that it disappears. First four bar are showing data of farmers up to one lac rupees of income. Another color that has covered major area in the graph is yellow of traders. We can see consistent pattern of the color yellow for below one lac income in the graph. Above Rs. 100000 income, yellow color is present in few bars only. Some bar shows the yellow color while in other bar it has been reduced up to nil. In last four bars the yellow area is almost removed. A blue bar that represents the shopkeeper, is consistently present in all the bars. 


\section{Frequency of Farmers in Different Range and Type of Sell}

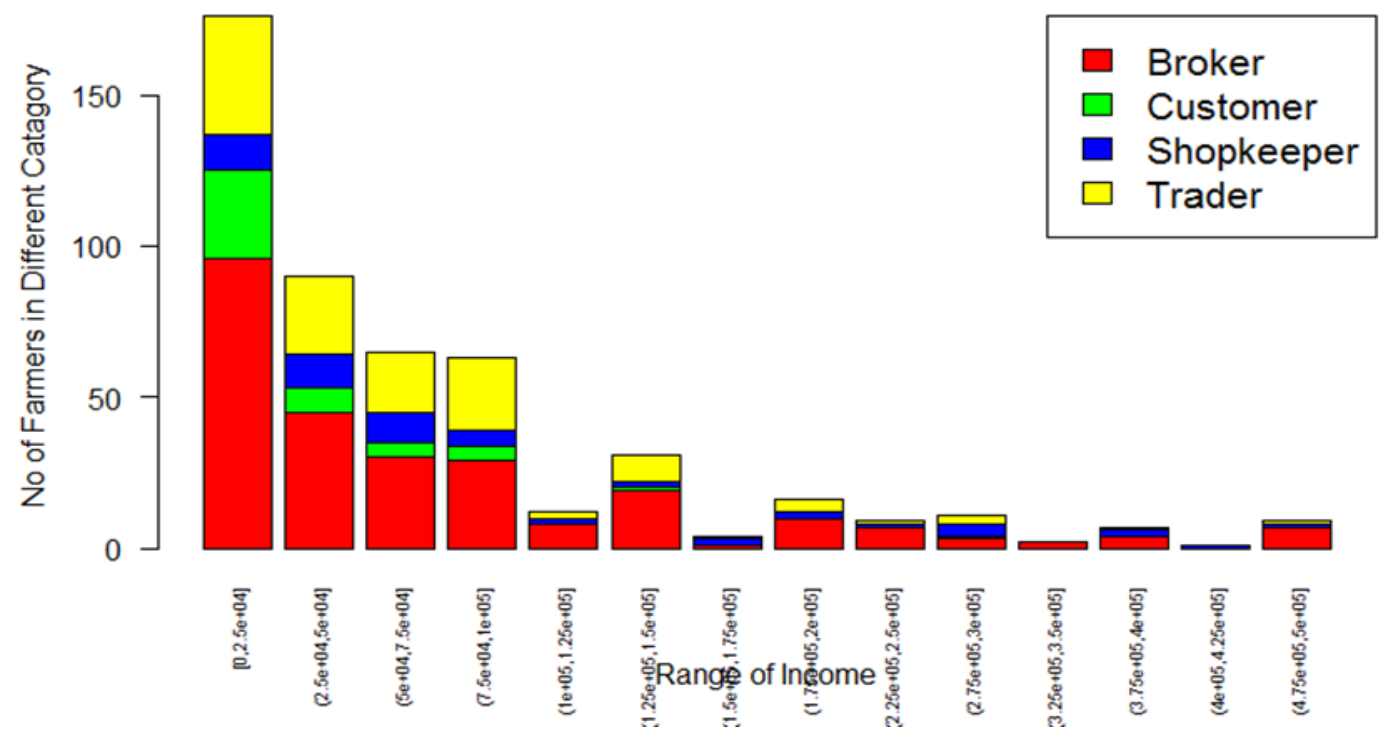

Figure 2: Different categories of entity by which farmers sell agriculture produce with different income range.

Auction in the APMC: Auction is another important parameter of APMC to purchase produce of farmers. Sometime due to one or other reasons auction could not take place, so far this process of purchase produce beneficial for farmers, it is necessary to find percentage of transactions occurs using auction. Here in this APMCAhmedabad, all farmers are not agree with the auction process of the produce. Given two graphs from the survey are about how many farmers are agree for auction take place while they go to sell their agriculture produce and how many are agree that auction indeed beneficence for them.

In APMC-Ahmedabad, auction process is known as "Hathrumal" process. Farmers and traders/brokers apply this method when they auction the produce. Majority farmers are agreed that they are selling produce on the status of their last few transactions in the APMC. In the survey, collected data shows that there are some farmers who disagree with the fact that auction takes place in APMC. 
Sustainability, Agri, Food and Environmental Research, (ISSN: 0719-3726), 8(X), 2020 http://dx.doi.org/10.7770/safer-VONO-art1995

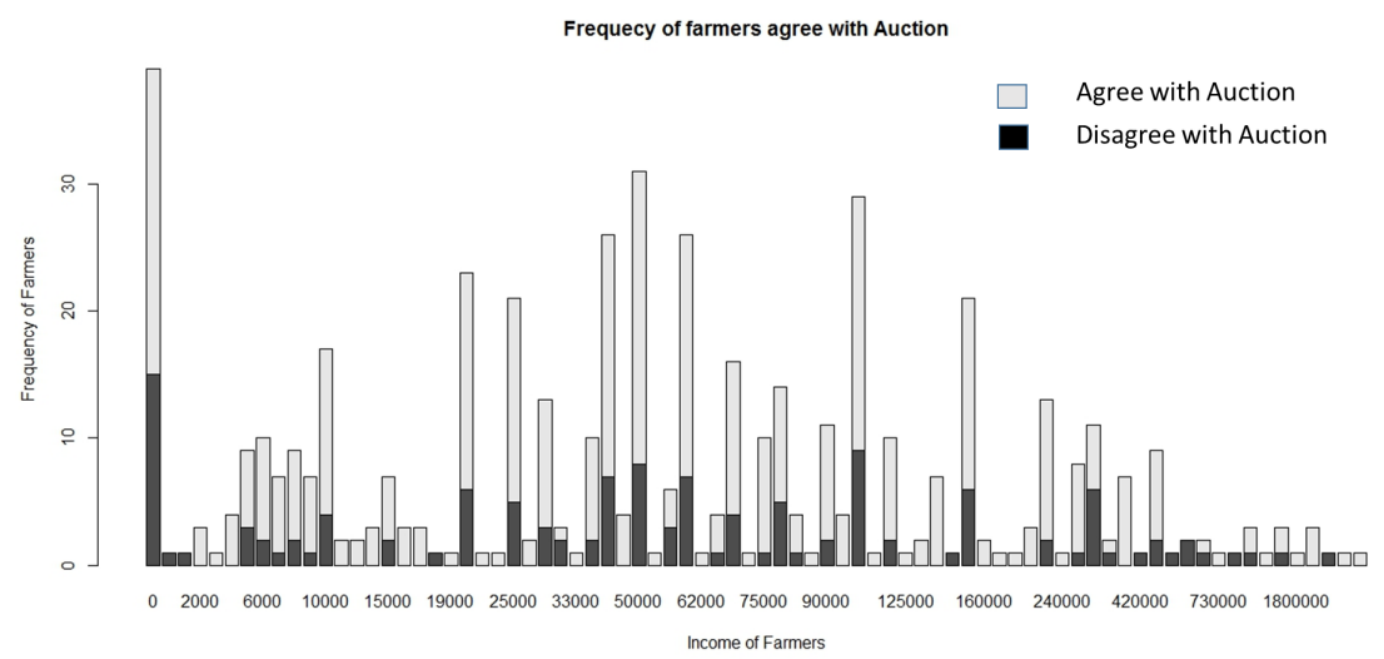

Figure 3: Graph of how many farmers agree with the auction take place at APMC in different income range

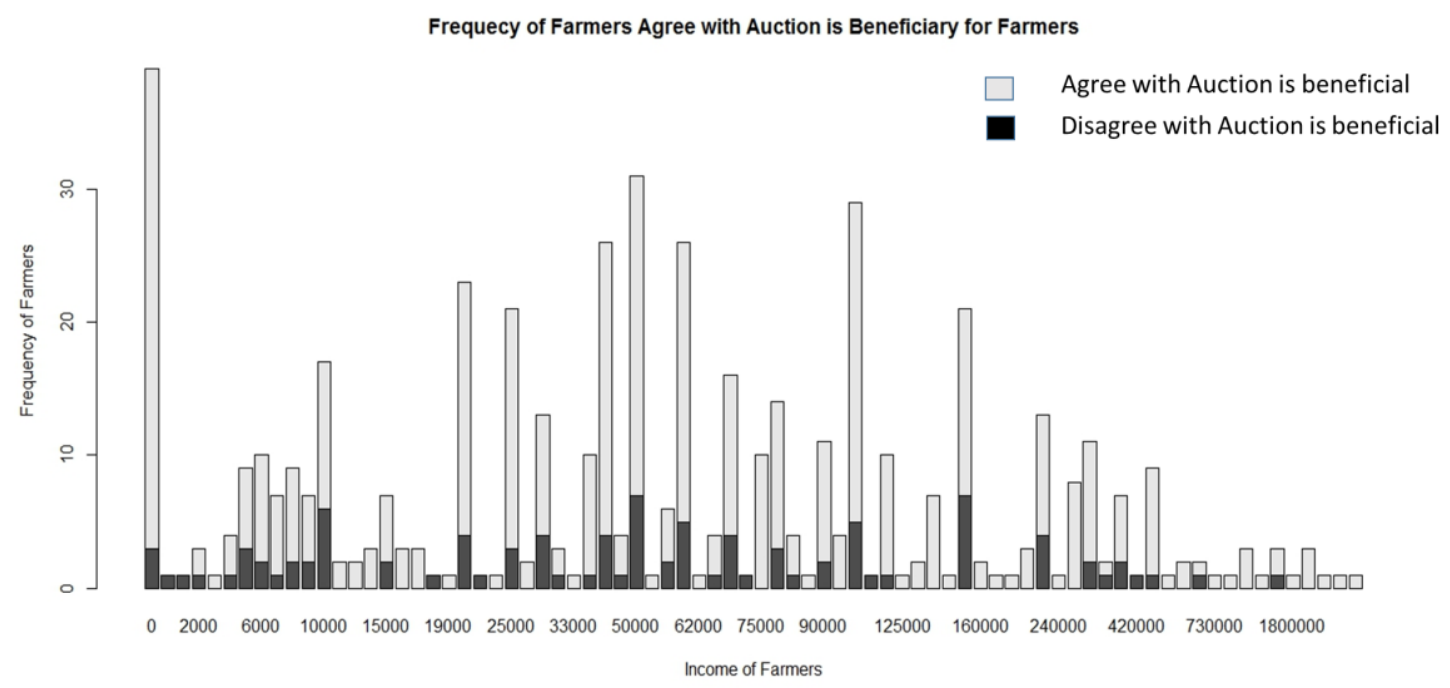

Figure 4: Graph of how many farmers find that auction is beneficial for the farmers at APMC

Auction is always beneficial for the farmers. This is the process by which farmers can have a good bargain for the produce among many traders/brokers. It is indeed beneficial for farmers to get more revenue of the produce if it is executed in 
proper manner. Graph in figure (3) shows the data about how many farmers are agree with the fact that auction is beneficial for the farmers. According to the graph, there are some farmers who disagree with the fact that auction is beneficial.

Graph of figure (4) shows data about how many farmers are disagree with fact that auction is beneficial. Here data has been deducted from above one and only those farmers who are agree with fact that auction take place in the APMC, considered for the response in the survey. There are 388 farmers are agreed for the auction take place in the APMC and among that all 40 are disagree with that auction is beneficial for the farmers.

Further Analysis for Auction: Income of the farmers, number of farmers within an income range and number of farmers agree to the auction are three different variables for the analysis. First we will define a correlation among three variables and then we will find a regression analysis of these data. Graph in figure (5.a) shows a correlation table among three variables, it shows that income is increases and number of farmer's decreases. Same is true for number of farmers agree to the auction take place in the APMC. While correlation between farmers and number of farmers agree with auction is positive and almost near to 1 . So we can predict that most of the farmers are agree with the fact that auction took place in the APMC.

Graph in figure (5.b) shows the three dimensional representation of number of farmers agree to the auction take place in the APMC for different income range. As appears in above data there are few instances of higher income range of farmers and so far income is increases the rate of agree to the auction is also decreases. The regression analysis will give a straight line if it is prepare for number of farmers and number of farmers agree to auction, but here in the 3D graph it shows income range too so we can identify the regression using multi variable through the graph. 
Sustainability, Agri, Food and Environmental Research, (ISSN: 0719-3726), 8(X), 2020 http://dx.doi.org/10.7770/safer-VONO-art1995

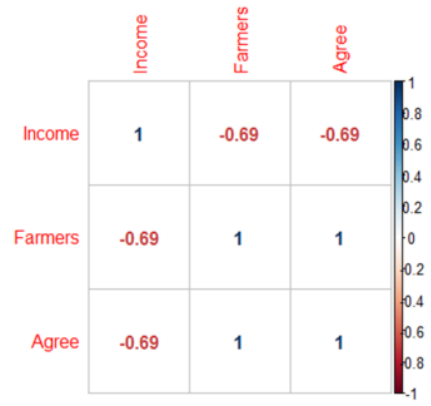

(a)
Farmers agree to Auction within differnet Income range

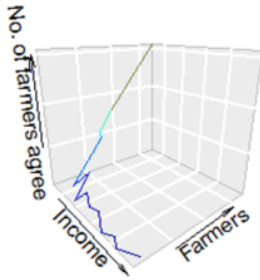

(b)

Figure 5: farmers agree for auction with reference to income. (a) Correlation coefficient matrix shows relation value with other parameters. (b) A 3-D plot that shows income of the farmers increases and number of farmers who satisfies with the auction process at APMC Decreases.

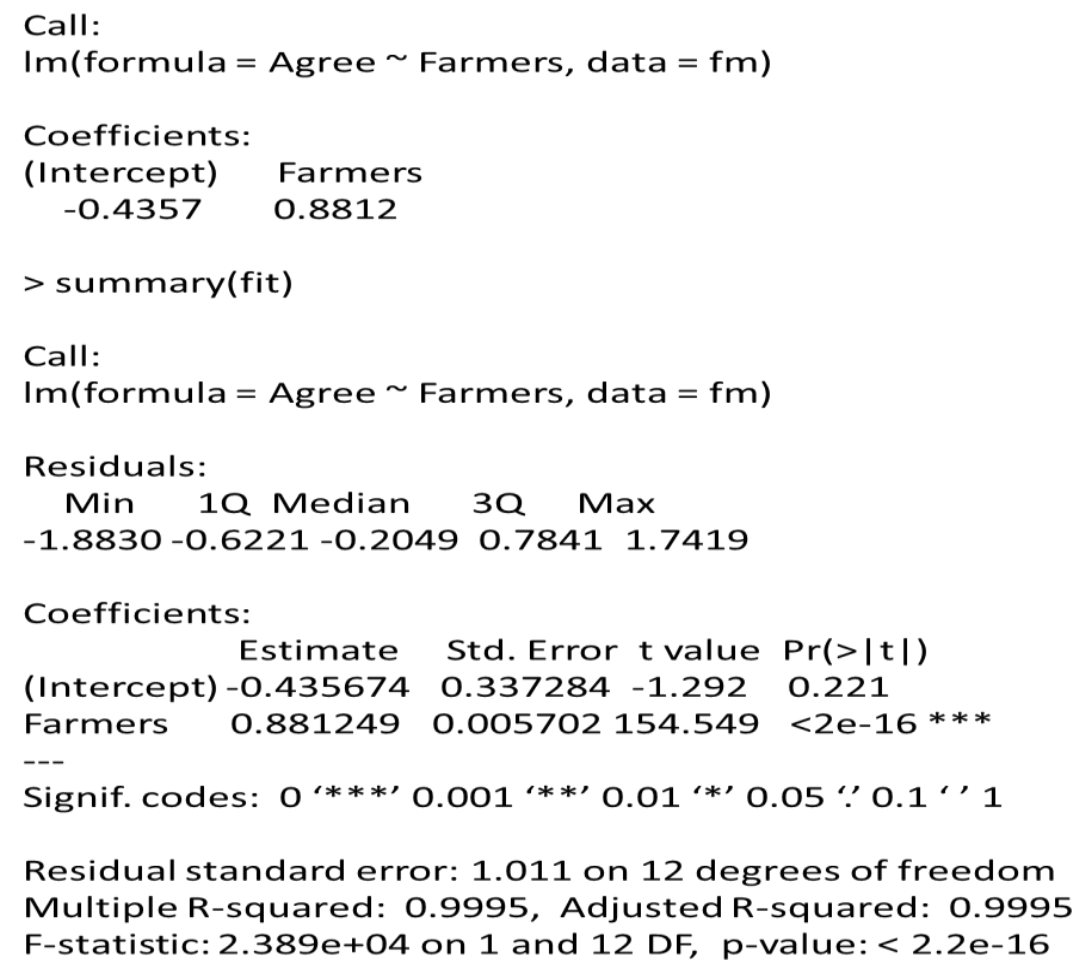

Figure 6: Regression model for the data of farmers and number of farmers agree with this process.

Linear regression on the data of number of farmers agree for the auction take place at the APMC is reduce as income of the parameter increases. According to figure (6) the value of coefficient intercept is -0.4357 and farmers is 0.8812 . This 
generates equation like Number of Farmer agree $=-0.4357+0.8812 * \mathrm{X}$ where $\mathrm{X}$ is reduction rate in next coming income range. $\operatorname{The} \operatorname{Pr}(>t)$ is used to find probability of observing any value equal or larger than $t$. A small $\mathrm{p}$-value indicates that it is unlikely we will observe a relationship between the predictor (Farmers) and response (Farmers agree to action) variables due to chance. A p-value of $5 \%$ or less is a good cut-off point. In our case regression model shows the $p$-value very close to zero. Three stars (or asterisks) represent a highly significant $p$-value. Consequently, a small $p$-value for the intercept and the slope indicates that we can reject the null hypothesis which allows us to conclude that there is a relationship between Agree and Farmers. Similarly there is a strong relationship between income and Number of farmers agree for auction. Given figure (7) shows both regression analysis.
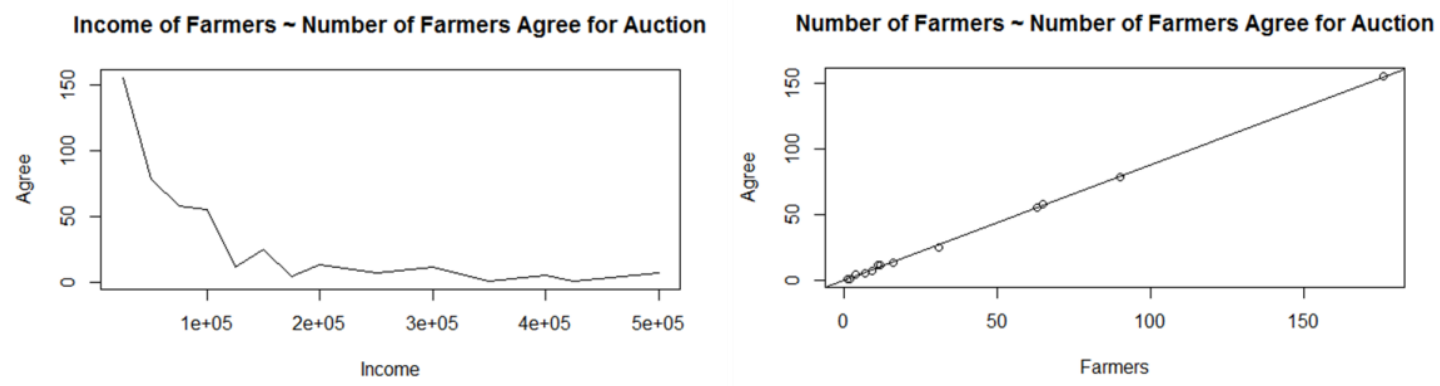

Figure 7: Regression Plot of Auction Data

Time frame of the Sell: Fruits and vegetables are perishable items, there is specific time frame to sell each fruits and vegetables otherwise they get spoil after sometime. People are interested to have very fresh produce while selling and buying such items. It is important for farmers to sell produce within good time frame so it remain fresh and get handsome revenue as well.

In the survey, collected data shows very few instances where farmers cannot sell produce in the appropriate time frame. There are only 71 instances among 517 of farmers, who said that their agriculture produce sometime not sold within time frame. While talking with secretory of APMC, they are getting approximately 25000 quintal to 27000 quintal of produce and Ahmedabad population can consume at most 9000 quintal of vegetable produce per day. It shows that there is good supply chain management between traders/brokers and buyer from other APMC, state or country. 
Sustainability, Agri, Food and Environmental Research, (ISSN: 0719-3726), 8(X), 2020 http://dx.doi.org/10.7770/safer-VONO-art1995

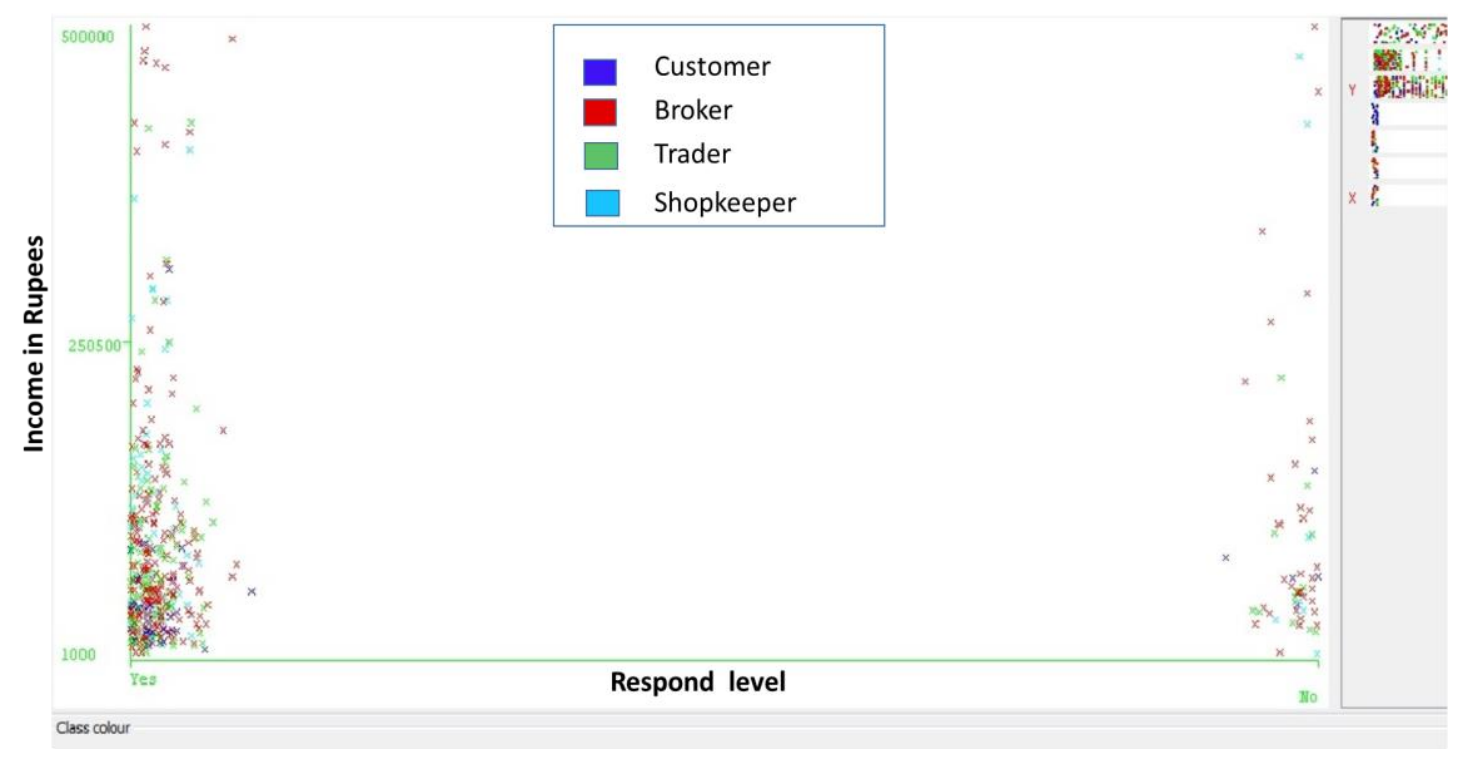

Figure 8: Data of farmers who are able to sell agriculture produces in required time frame. X-dimension data shows 'Yes' who are agree and 'No' who are disagree.

The graph in figure 8 shows that how many farmers agree for the produce had been sold in required time frame. Graph has two columns and there is no relationship between their income range and their response. If we again take a closer look of this data then we have more information about such sell of farmers. This figure shows data about farmer's response of the question whether they can sell produce within required time frame. Again this graph shows three dimensional data of sell, on $X$ dimension has response in 'Yes' or 'No'. $Y$ dimension has income range and color of the points as third dimension which shows generally to whom farmer sell produce. According to graph, there is no relationship between income range and farmer's response but we can find out how many famers not able to sell produce within required timeframe. Data shows that there are five instances of farmer who sell produce to end customers and their income is less than one lac with response 'No'. Similarly there are only five instances of farmer who sell to the shopkeeper for income less than one lac but for higher income there are few more farmers who are not able to sell produce to shopkeeper within time frame. It deduces that farmer who sell to the shopkeeper faces difficulties for produce to be sold within specific time frame. Farmers who work with brokers are facing same problems whether their produce is large or small. 
Data about traders are more interesting. There are instances of farmer who sell produce to traders and produce had not been sold within a time frame. These instances are occurred below 2.5 lacs of income range. It is to be noted that there is no such instance of framer who couldn't sell within time frame to traders in higher income range. It shows that farmers who belong to higher income range can sell produce within time frame to traders if their produce is large in quantity. Traders can buy large amount of produce where for lesser amount of produce there are chances that traders may not have interest to buy produce of farmers.

Unsold Produce: Produce that is not sold within a time frame is unsold produce. In the survey, there is a key question for farmers what they do if produce is not sold in the market. This question is important to know about farmer's awareness regarding market information and supply chain management. If farmers know about other market and their rate, he/she will definitely calculate the risk to sell produce in other market with transportation and other expenses. If he/she found that in current scenario it is difficult to get good rate then cold storage is also good option and they can sell out whenever good rates are available. This way they can also strengthen the supply-chain management in the country.

In the survey, we got various answers for how they manage these unsold produce. According to above data there are only 71 instance of such farmers whose produce is unsold. We have manually analyzed the data for their choices to do with unsold produce. In this analysis we got 47 clear responses of farmers. Given table 4 shows the data of various choices of farmers to do with unsold produce.

As shown in the table (4) only nine farmers stores their produce in the cold storage when they do not get good market price of produce. These farmers need efficient supply-chain for perishable items so it can be well preserve and distributed through required atmosphere using refrigerated wagon. They also need to aware themselves about estimation of demand and market trends with reference to national and international market. Here the most upsetting figure is farmers who throw it to garbage with fourteen in numbers. 
Sustainability, Agri, Food and Environmental Research, (ISSN: 0719-3726), 8(X), 2020 http://dx.doi.org/10.7770/safer-VONO-art1995

Table 4: Table of farmer's choice for the unsold agriculture produce

\begin{tabular}{ll}
\hline Various Choices of Farmers Opt to do with Unsold Produce & $\begin{array}{l}\text { Number of } \\
\text { Instances }\end{array}$ \\
\hline Farmers store it in the cold storage & 9 \\
Farmers sell produce at less price & 4 \\
Farmers sell produce after few days if possible & 1 \\
Farmers send produce to other APMC or market & 4 \\
Farmers sell produce at free of cost to relatives or neighbors & 3 \\
Farmers use produce to make compost & 3 \\
Farmers use produce for cattle food & 14 \\
\hline
\end{tabular}

As conclusion, in the paper, analysis of farmers, to whom they like to sell produce is shown with graph. APMC has large amount of traders and brokers. Mainly farmers are selling produce through them only. End-customers and farmers are not doing business end to end. Possibility of large chunk can be taken by traders and brokers is always there.

Auction is taken place but it is benefited to farmers is not clear. Conventional process at APMC allow auction but 40 farmers were not agree. Alternative of this process is absent. Farmers are not well informed about local market and international market, sometime it seems that they are following others footsteps. Education must encourage them to know more about other markets and other produce.

Time frame of the sell in APMC for any produce depend on the quantity of produce. Small farmers (less amount of produce) are not able to sell their produce, whereas large amount of produce get sold through current chain of people. 
There are many problems in India for fresh fruits and vegetables supply chain management. The problems like numerous stack holders working in isolation, lack of demand estimation, lack of technology applications, lack of system integration and presence of large unorganized retailers Neepa Shah (2017) are persist at all regulatory body. Unsold produce statistics shows that $13 \%$ to $15 \%$ produce is wasted by lack of information or absence of facilities like cold storage, or refrigerated wagons.

\section{REFERENCES}

Amarender R., 2015. Regional Disparities in Profitability of Rice Production: Where Small Farmers Stand? Indian Journal of Agriculture Economy, 70, 259-271.

Agricultural Situation in India. May 2015. Directorate of Economics and Statistics, Department of Agriculture and Cooperation Ministry of Agriculture.

Angad Singh Maravi, April 2015, Performance Analysis of Indian Agricultural Commodity Market. International Journal of Commerce, Business and Management (IJCBM), 4, 1125-1136

K. Paty, April-June, 2005, Marketing Costs and Margins of Agricultural Produce in Tripura, Agricultural Marketing I, PAMA-116, VOL.-XLVIII, 1

Chandra, P., \& Kar. A., 2005. Issues and Solutions of Fresh Fruits Export in India. Indian Council of Agricultural Research.

Dev, S.Mahendra. June 2012. Small Farmers in India: Challenges and Opportunities." Indira Gandhi Institute of Development Research, Mumbai, Retrieved December 2016 (http://www.igidr.ac.in/pdf/publication/WP-2012014.pdf)

Directory Of Wholesale Agricultural Produce Assembling Markets In India, 2004, Government Of India Ministry Of Agriculture (Department Of Agriculture \& Cooperation)Directorate Of Marketing \& Inspection

Gandhi, V., \& Namboodiri, N.V., 2004, Marketing of Fruits and Vegetables in India: A Study Covering the Ahmedabad, Chennai and Kolkata Markets" Centre for Management in Agriculture, Indian Institute of Management, Ahmedabad.

Gandhi, V., 2010. Fruit and vegetables marketing and its efficiency in India - a study of wholesale market in the Ahmedabad area. Centre for Management in Agriculture, Indian Institute of Management, Ahmedabad. 
Sustainability, Agri, Food and Environmental Research, (ISSN: 0719-3726), 8(X), 2020 http://dx.doi.org/10.7770/safer-VONO-art1995

Gaurav B., Vijay Vyas 2014. Study of Infrastructural Status in Agriculture Marketing. Indian Journal of Research, 4, 90-99

Horticultural Statistics at a Glance. 2015. Horticulture Statistics Division, Department of Agriculture, Cooperation \& Farmers Welfare Ministry of Agriculture \& Farmers Welfare.

Kiran Sankar Chakraborty, 2005, Marketing Costs and Margins of Agricultural Produce in Tripura, Agricultural Marketing, PAMA-116, XLVIII, 31-38

Neepa, Shah 2017, Delisting of Fresh Agriculture Produce and Problems of Farmers: A Proposed Model for Farmers and End Consumer to Build an Interface using ICT", Vidyapith, April-June 2017, 2. 86-100

Negi, S., \& Anand, N., 2015. Issues and Challenges in the supply. International Journal of Managing Value and Supply Chains International Journal of Managing Value and Supply Chains (IJMVSC), 6, 47-62

Praduman K., Anjani, K., \& Shinoj Parappurathu \& Raju, S.S., 2011, Estimation of Demand Elasticity for Food Commodities in India. Agricultural Economics Research Review, 24, 1-14

Prasad, R., \& Satsangi,Rupali. January-2013. A Case Study of AMUL Cooperative in India in Relation to Organizational Design and Operational Efficiency. International Journal of Scientific \& Engineering Research, 4,

Praveen K.V., \& Suresh, A., 2015. Performance and Sustainability of Kudumbashree Neighbourhood Groups in Kerala: An Empirical Analysis. Indian Journal of Agriculture Economy, 70, 417-425

Saxena, M., 2014. Indian Horticulture database, Dept. of Agri. \& Coop.

Singh, S., and Singla, N., 2010. Fresh Food Retail Chains in India: Organization and Impacts. CMA Publication.

Tiwari, R.K., 2013. Indian Horticulture database, Dept. of Agri. \& Coop.

Vadivelu, A., \& Kiran, B.R. 2013 Problems And Prospects of Agriculture Marketing in India": An Overview" International Journal of Agricultural and Food Science, 3, 108-118 